\title{
RETHINKING PARLIAMENTARY STATUS: ARE PARLIAMENTARIANS BOUND BY THE PROTECTED DISCLOSURES ACT 2000? A COMPARISON BETWEEN SOUTH AFRICA AND NEW ZEALAND
}

\author{
Luke Hilton*
}

This article compares the Protected Disclosures Act 2000 (PDA) in South Africa and New Zealand. The comparison is framed by the question whether the PDA binds members of Parliament (MPS) or not. Regarding South Africa, the article analyses the provisions of the PDA and its curial interpretation in the Charlton litigation. Technically, MPs are bound by the PDA. This article nonetheless defends the Labour Appeal Court's merits judgment, which held that MPs are not bound. Regarding New Zealand, the article analyses the provisions of the PDA and suggests the probable outcome in court if similar litigation were ever to occur in New Zealand.

\section{INTRODUCTION}

This article concerns the theory of the relationship between the judiciary and the legislature. ${ }^{1}$ More narrowly put, the article is about lawmakers and a particular law that they happened to make. It compares the Protected Disclosures Act 2000 (PDA) in both South Africa and New Zealand. The comparison is framed by the question whether the PDA binds members of Parliament (MPs) or not.

The origin of this question began in South Africa with a trio of cases attracting some media and academic attention. Approximately a decade ago, Mr Charlton, the Chief Financial Officer of Parliament, made allegations about misconduct by some MPs in relation to their alleged misuse of

* LLB, University of Cape Town; LLM, Victoria University of Wellington; Practising Solicitor (Wellington, New Zealand). I would like to thank Sir Grant Hammond for his guidance and encouragement.

1 Robert French, Chief Justice of the High Court of Australia "The Courts and the Parliament" (Queensland Supreme Court Seminar, Brisbane, Australia, 4 August 2012) at 12. 
travel benefits. Mr Charlton was dismissed after a disciplinary enquiry. He approached the Labour Court claiming that he had made disclosures that were protected under the PDA. Parliament raised several exceptions. The relevant one was that Mr Charlton had not made protected disclosures because MPs were neither the employer of nor the employees of Mr Charlton for the purposes of the PDA; accordingly, Mr Charlton had failed to disclose a cause of action. The Labour Court dismissed the exception. ${ }^{2}$ Parliament appealed. The Labour Appeal Court upheld the appeal. ${ }^{3}$ Mr Charlton, in turn, appealed. The Supreme Court of Appeal upheld his appeal on a technical ground. ${ }^{4}$ Effectively, the law is now as stated by the Labour Court. This article nonetheless supports the Labour Appeal Court's merits judgment and defends it against strong academic criticism.

This article is divided into three main parts. The first deals with parliamentary status. MPs are different from ordinary citizens because of the office they hold. This part briefly discusses the facets of parliamentary status as globally understood in parliaments across the world. The article will then identify some definitional issues regarding MPs. How are they to be viewed by the public? How do you define their work portfolio?

The second part deals with South African constitutional law and begins by setting out the country's fundamental structure. It thereafter analyses the PDA and the Charlton cases. The article also discusses several cases relating to parliamentary conduct and the authority of the Speaker of the National Assembly. The relationship between the judiciary and the legislature has come to the fore in recent times. The Labour Appeal Court's merits judgment is more relevant than ever. The article then discusses academic criticism of the judgment and thereafter offers a rejoinder to this criticism.

The third part deals with New Zealand constitutional law and begins by setting out its fundamental structure. The article then analyses the PDA within the applicable legislative framework. The equivalent of the Charlton saga has not occurred in New Zealand. The article briefly discusses the probable outcome in court if it were ever to happen.

2 Charlton v Parliament of the Republic of South Africa [2007] ZALC 47, [2007] 10 BLLR 943 [Charlton (LC)].

3 Parliament of the Republic of South Africa v Charlton [2010] ZALAC 13, [2010] 10 BLLR 1024 [Charlton (LAC)].

4 Charlton v Parliament of the Republic of South Africa [2011] ZASCA 132, 2012 (1) SA 472 [Charlton (SCA)]. 


\section{PARLIAMENTARY STATUS}

\section{A Globally Understood}

Marc van der Hulst's The Parliamentary Mandate: A Global Comparative Study was published on behalf of the Inter-Parliamentary Union. ${ }^{5}$ One of its parts deals with parliamentary status. The author defines status as being about the "advantages and responsibilities designed to safeguard the free exercise of their mandate and protect them against pressures that might undermine their independence". 6

Parliamentarians enjoy four different kinds of status. The first concerns salaries and allowances. This is integral to the status of MPs. ${ }^{7}$ South Africa has the Remuneration of Public Office Bearers Act 1998. New Zealand has the Members of Parliament (Remuneration and Services) Act 2013.

The second concerns parliamentary incompatibilities, which are designed to guarantee independence. $^{8}$ This kind of status originates in the doctrine of separation of powers. ${ }^{9}$ There are different categories of incompatibility. The relevant category is that of incompatibility with nonelective positions such as a civil service post. ${ }^{10}$ In South Africa, the Constitution states that "anyone who is appointed by, or is in the service of, the state and receives remuneration for that appointment or service" is ineligible to serve as a member of the National Assembly. ${ }^{11}$ In New Zealand, the Michael Connelly Appointment Validation Act 1936, a private Act, provides a clear example of a similar incompatibility regime. Mr Connelly had been summoned to the Legislative Council (now abolished) but was disqualified to serve as a member because he was a civil servant; $s$ of the Act validated his appointment and deemed him duly summoned. It is submitted that this is a rare exception.

The third kind of status enjoyed by MPs is that of parliamentary immunity. ${ }^{12}$ MPs are representatives of the people and as such must be afforded various guarantees so as to underscore the "dignity, gravity and importance of their office"; 13 they must also enjoy "peace of mind" in the

5 Marc van der Hulst The Parliamentary Mandate: A Global Comparative Study (Inter-Parliamentary Union, Geneva, Switzerland, 2000).

6 At 27

7 At 28.

8 Hulst, above n 5, at 44.

9 At 44 .

10 At 45.

11 Section 47(1)(a).

12 Hulst, above n 5, at 63.

13 At 63. 
discharge of their mandate. ${ }^{14}$ MPs enjoy parliamentary "non-accountability" or privilege. ${ }^{15}$ This relates to freedom of speech. ${ }^{16}$ But they also enjoy parliamentary immunity, which concerns potential fear of the executive and includes protection against arrest. ${ }^{17}$ South Africa has the Powers, Privileges and Immunities of Parliament and Provincial Legislatures Act 2004 (Privileges Act). New Zealand has the Parliamentary Privileges Act 2014.

The last kind of status enjoyed by MPs is that relating to their rank in the hierarchy in Parliament. ${ }^{18}$ Generally, there is a principle of equal status of MPs; MPs are elected on the basis of uniform principles laid down in electoral legislation. ${ }^{19}$ But there is still a pecking order. Parliaments across the global recognise precedence based on office and the primacy of the Speaker, which, in the United Kingdom, embodies the authority of the legislature. ${ }^{20}$ In countries following the parliamentary tradition the hierarchy proceeds as follows: (1) Speaker; (2) Deputy Speaker; (3) Leader of Majority; (4) Leader of Opposition; (5) Majority Whip; (6) Opposition Whip; and (7) ordinary members ranked according to seniority. ${ }^{21}$

This article argues that any attempt to interpret parliamentary office must take into account the above hierarchy. Simply put, if MPs are interpreted to be "employees" for the purposes of the PDA, then this would bind the Speaker, as an MP, in the same way as it would bind an ordinary MP. But the Speaker is meant to embody the authority of the legislature. Similarly, if an ordinary MP were interpreted to be an "employer", then this would also undermine parliamentary hierarchy since an ordinary MP would be seen as an authority figure on the same level as the Speaker.

\title{
B Definitional Issues
}

Parliamentary status makes the task of defining an MP's role in society quite difficult. Where do MPs fit in? How should they be seen by the public? Geoffrey Palmer argues that it is hard for an MP to know what task to focus on because there are so many that have to be carried out. ${ }^{22}$ There is no adequate "job definition" for an MP. ${ }^{23}$ In the main, MPs represent their electorates and the people in

\author{
14 At 63. \\ 15 At 65. \\ 16 At 68. \\ 17 At 78 . \\ 18 At 94 . \\ 19 At 94 . \\ 20 At 95. \\ 21 At 96. \\ 22 Geoffrey Palmer Reform: A Memoir (Victoria University Press, Wellington, 2013) at 270. \\ 23 At 269 .
}


their constituency by presenting their grievances to Parliament. ${ }^{24}$ MPs have lots of material to read: Bills, government reports and reviews tabled in the House, select committee submissions, constituent correspondence and paperwork in preparation for numerous meetings. ${ }^{25}$ Should MPs be viewed as people with a serious role in making law, scrutinising legislation, finding anomalies in Parliament and contributing to the policy of the government of the day? Or should they be a "watchdog" for the people in respect of executive action? Or should they be "mindless servant[s]" of their political parties and vote as the party dictates? ${ }^{26}$ One issue facing MPs is how best to allocate tasks and manage their time. $^{27}$

Palmer notes that, from an MP's perspective, Parliament takes on a different "hue" from that seen by members of the ordinary public. ${ }^{28}$ From a lawyer's perspective, the role of Parliament is that of lawmaker and the interest lies in legislative clarity and coherence. ${ }^{29}$ The functions of Parliament are as follows: it raises money by which the business of government is conducted; it approves expenditure; it considers and passes laws; it provides a forum for the voicing of grievances; it holds the executive to account; and it provides a forum for parley or debate. ${ }^{30}$ These different perspectives on the role of Parliament also apply in South Africa despite its different fundamental structure.

\section{SOUTH AFRICA}

\section{A Fundamental Structure}

South Africa has a codified Constitution, which is the supreme law of the land. ${ }^{31}$ The doctrine of separation of powers is integral to the constitutional order; it concerns the distribution of power amongst the executive, the legislature and the judiciary; ${ }^{32}$ the doctrine divides the functions of constitutional government between the branches best suited to exercise the relevant duties efficiently and effectively; the legislature is best equipped to make law, the executive to administer it and the

24 At 269 .

25 At 269 .

26 At 270 .

27 At 270

28 At 363 .

29 At 363

30 At 364

31 Section 2.

32 Dikgang Moseneke, Deputy Chief Justice of South Africa "Separation of Powers: Have the Courts Crossed the Line?" (Inaugural Annual Law Dean's Distinguished Lecture, University of the Western Cape, Cape Town, 17 July 2015) at 5. 
judiciary to interpret and apply it. ${ }^{33}$ The doctrine is not rigidly defined, nor is it absolute. ${ }^{34}$ The system of checks and balances forms part of the doctrine; the general purpose of checks and balances is to make the branches of constitutional government accountable to one another; checks ensure that the different branches control one another internally; balances concern the counterweight to power possessed by each of the branches; the system of checks and balances can be seen as an audit. ${ }^{35}$

The Constitution does not expressly provide for separation of powers but the doctrine is nonetheless an intrinsic part of constitutional democracy. ${ }^{36}$ Section 43 vests legislative authority in Parliament, s 85 vests executive authority in the President and s 165 vests judicial authority in the courts. While separation of powers is not named in the Constitution, it is accepted as the "dominant organising principle of state power". ${ }^{37}$

Courts have refrained from trespassing into the terrain of another branch of government; they have recognised the need to defer to Parliament on occasion; this is particularly so in matters involving polycentric issues. ${ }^{38}$ The merits of disputed legislation fall outside the remit of a court. ${ }^{39}$

The relationship between the branches of constitutional government is not designed to be competitive but rather symbiotic. ${ }^{40}$ However, this has not always been the case. In the 1950s South Africa came close to a constitutional crisis. The Union Parliament tried to remove coloured voters from the common voters roll. The Appellate Division invalidated the offending legislation. ${ }^{41}$ But Parliament purported to create a "High Court of Parliament" in order to override undesirable appellate decisions. ${ }^{42}$ The matter came before the Appellate Division again and it ruled that the "High Court of Parliament" was not a court but rather Parliament under another name. ${ }^{43}$ The crisis concerned the meaning of Parliament.

This article focuses on Parliament in the new constitutional dispensation. Terminologically, and in the national sphere, the Constitution refers to "Parliament", "membership", "National Assembly"

33 At 6.
34 At 6.
35 At 7.
36 At 8.
37 At 8
38 At 9.
39 At 9.
40 At 15.
41 At 15.
42 At 16.
43 At 16.


and members' "privilege". ${ }^{44}$ Parliamentary power is exercised collectively and individually. The power to initiate or prepare legislation is not an exclusively collective power exercised by the National Assembly. ${ }^{45}$ The making of decisions by way of majority vote is an exercise of collective power. ${ }^{46}$ But the power to initiate or prepare legislation can be exercised individually by MPs. ${ }^{47}$ Parliamentary privilege is enjoyed by Cabinet members, Deputy Ministers and MPs. ${ }^{48}$

\section{B Charlton Controversy}

Eighteen years ago Parliament enacted the PDA. But the legislation could have looked very different. As will be seen below, Parliament could have passed the Open Democracy Act instead.

\section{Brief history of the Protected Disclosures Act}

The PDA began as the Open Democracy Bill 1998. ${ }^{49}$ This was a generic Bill. But Parliament chose to split this into two separate and discrete enactments, namely, the Promotion of Access to Information Act 2000 and the PDA.

Legislative drafters are often faced with the generic-discrete or "magic bullet" dilemma. ${ }^{50}$ In the context of protected disclosures, the dilemma would be as follows: should there be a single, comprehensive, narrowly targeted discrete enactment, or, should the issue of protected disclosures be tacked onto generic legislation ${ }^{51}$ Generic legislation has the effect of bringing the subject-matter of the legislation into the mainstream. ${ }^{52}$ Discrete legislation grants specific rights; ${ }^{53}$ it would also concomitantly impose specific duties.

Parliament exercised a legislative choice in dropping the generic Open Democracy Bill and pursuing the enactment of discrete legislation instead. In the United Kingdom, the Public Interest Disclosure Act 1998, which is discrete legislation, was inserted into the Employment Rights Act 1996,

44 Sections 42, 47, 49, 55 and 58 .

45 Oriani-Ambrosini, MPv Sisulu, MP, Speaker of the National Assembly [2012] ZACC 27, 2012 (6) SA 588 at [32]; and The Constitution of the Republic of South Africa 1996, s 55(1)(b).

46 At [37]; and The Constitution of the Republic of South Africa, s 53.

47 At [40]; and The Constitution of the Republic of South Africa, ss 55(1)(b) and 73(2).

48 The Constitution of the Republic of South Africa, s 58(1).

49 Open Democracy Bill 1998 (B67-1).

50 H Rutherford Turnbull "Rights for Developmentally Disabled Citizens: A Perspective for the 80s" (1981) 4 UALR 400 at 422

51 At 422 .

52 At 427

53 At 427 
which is a generic statute. In contrast, South Africa pushed in the opposite direction; the legislature moved away from a generic Bill and toward discrete legislation. New Zealand's PDA does not define "employer" since there is no demonstrable need to do so in the context of completely discrete legislation on protected disclosures. The United Kingdom defines "employer" because its law on public interest disclosures forms part of a generic statute. South Africa is stuck in the middle. While the Open Democracy Bill did not define "employer", the legislature chose to define it in the PDA. In terms of legislative approach, South Africa has one foot in the United Kingdom by defining "employer" in the PDA and the other foot in New Zealand by enacting completely discrete legislation.

Returning to the Charlton controversy, it is clear that the courts - the Labour Court, the Labour Appeal Court and the Supreme Court of Appeal - arrived at divergent views on the proper interpretation of the applicable legal framework. The question is whether this divergence is the result of judicial error in construing the framework or the framework itself.

\section{The Protected Disclosures Act}

The PDA is set within the employment law context. This is clear from a recent amendment that inserted "worker" and defined it. ${ }^{54}$ It is also clear from its long title, which describes the objective of the Act. ${ }^{55}$ The long title reads:

To make provision for procedures in terms of which employees in both the private and the public sector may disclose information regarding unlawful or irregular conduct by their employers or other employees

in the employ of their employers; to provide for the protection of employees who make a disclosure which

is protected in terms of this Act; and to provide for matters connected therewith.

Notably, the Constitution specifically refers to "employees" in the context of public service within the public administration, and "employers" in the context of labour relations in the Bill of Rights. ${ }^{56}$ Regarding employees, the Public Service Commission has the power to investigate grievances of employees in the public service concerning official acts or omissions; ${ }^{57}$ the Commission also has the power to advise national and provincial organs of state on various aspects relating to the careers of employees in the public service; ${ }^{58}$ and the Constitution provides that public service employees are entitled to a fair pension as regulated by national legislation. ${ }^{59}$ Regarding employers, the Bill of Rights

54 Section 1(g) of the Protected Disclosures Amendment Act 2017. This article will use the wording of the Protected Disclosures Act 2000 (SA) as it applied at the time of the Charlton controversy.

55 Bertie Van Zyl (Pty) Ltd v Minister for Safety and Security [2009] ZACC 11, 2010 (2) SA 181 at [43].

56 Sections 196-197 for "employees" and s 23 for "employers". The Bill of Rights is found in ch 2 of The Constitution of the Republic of South Africa.

57 Section 196(4)(f)(ii).

58 Section 196(4)(f)(iv)

59 Section 197(2). 
provides that employers have the right to form an organisation and participate in the activities and programmes of that organisation ${ }^{60}$ and every employer has the right to engage in collective bargaining. ${ }^{61}$ The Constitution does not define either "employee" or "employer".

This article argues that these references are significant as they provide the only constitutional basis for the use of "employee" or "employer" in national legislation binding organs of state. The Constitution is the supreme law and any law inconsistent with it is invalid. ${ }^{62}$ Viewed from this perspective, there would be no constitutional basis on which to hold that MPs are either "employees" or "employers" for the purposes of the PDA. As stated above, anyone employed in the service of the state is ineligible to serve as an MP and the Constitution's references to "employees" occur in the context of the public service. Furthermore, the constitutional rights of employers to form an organisation and to engage in collective bargaining are provided for in the Labour Relations Act 1995 (LRA), which does not apply to MPs. Regarding MPs, this article submits that the PDA's references to "employee" and "employer" can only be interpreted in the sense specifically provided for in the Constitution.

The preamble to the PDA also refers to "employees" and "employers" as well as phrases such as "conduct in the workplace". It also recognises the horizontal application of the Bill of Rights. The preamble further recognises that criminal and other irregular conduct on the part of organs of state is detrimental to transparent and accountable governance. It also states that the PDA was enacted in order to create a culture facilitating the disclosure of information relating to criminal or other irregular conduct in the workplace; this disclosure must take place in a responsible manner through the provision of "comprehensive statutory guidelines" for such disclosure.

The PDA defines "employer", "employee", "disclosure" and "protected disclosure". ${ }^{3}$ Generally, it is not permissible to use the meaning attributed to words in other statutes as determinative in the interpretation of words used in a different statute. ${ }^{64}$ Statutory definitions are taken to bear a special meaning and not an ordinary meaning. ${ }^{65}$ But the definition of a word in other statutes might be relevant if they "traverse the same terrain". 66

60 Section 23(3).

61 Section 23(5).

62 Section 2.

63 Section 1.

64 Minister of Defence v Thomas [2015] ZACC 26, 2016 (1) SA 103 at [20].

65 At [20].

66 At [20]. 
One of the functions of a statutory definition is to limit the operation of the statute. ${ }^{67}$ While the extensive use of a word throughout an enactment may point to the need for a definition, ${ }^{68}$ this cannot be seen as an absolute rule. What if the office of an MP straddles the definition of "employee" and "employer" ${ }^{69}$ This article reiterates that part of the interpretive difficulties experienced by the courts in the Charlton case arose in part because of the legislative choice to define "employer". The PDA defines "employer" as follows: ${ }^{70}$

(a) who employs or provides work for any other person and who remunerates or expressly or tacitly undertakes to remunerate that other person; or

(b) who permits any other person in any manner to assist in the carrying on or conducting of his, her or its business,

including any person acting on behalf of or on the authority of such employer ...

It is unclear as to why the legislature chose to define "employer" other than the fact that the word is used throughout the Act. But any interpretation of "employer" must be consistent with the Constitution's reference to "employer". It is submitted that the use of "employer" in the PDA must be understood in its constitutional sense, namely, as applying within the labour law context as regulated primarily by the LRA.

The PDA's definition of "employee" replicates the definition contained in earlier enactments, namely, the LRA and the Basic Conditions of Employment Act 1997 (BCEA). The PDA defines "employee" as follows: ${ }^{71}$

(a) any person, excluding an independent contractor, who works for another person or for the State and who receives, or is entitled to receive, any remuneration;

(b) any other person who in any manner assists in carrying on or conducting the business of an employer $\cdots$

The PDA defines "disclosure" and "protected disclosure" separately. This article only quotes the relevant subparagraph of the definition of "disclosure", which reads as follows: ${ }^{72}$

67 My Vote Counts NPC $v$ Speaker of the National Assembly [2015] ZACC 31 at [97].

68 At [100].

69 Adapting the reasoning at [108].

70 Section 1.

71 Section 1.

72 Section 1. 
[A]ny disclosure of information regarding any conduct of an employer, or an employee of that employer, made by any employee who has reason to believe that the information concerned shows or tends to show one or more of the following:

(a) That a criminal offence has been committed, is being committed or is likely to be committed ...

The definition of "protected disclosure" sets out various categories of person to whom disclosures can be made. The definition reads as follows: ${ }^{73}$

[A] disclosure made to-

(a) a legal adviser in accordance with section 5;

(b) an employer in accordance with section 6;

(c) a member of Cabinet or of the Executive Council of a province in accordance with section 7;

(d) a person or body in accordance with section 8; or

(e) any other person or body in accordance with section 9, but does not include a disclosure-

(i) in respect of which the employee concerned commits an offence by making that disclosure; or

(ii) made by a legal adviser to whom the information concerned was disclosed in the course of obtaining legal advice in accordance with section $5 \ldots$

The PDA is clear that employees making protected disclosures must not be subjected to occupational detriment. ${ }^{74}$ The PDA provides such employees with various remedies in the event that they suffer occupational detriment. ${ }^{75}$ One remedy is to approach the Labour Court for appropriate relief. $^{76}$ The PDA provides that dismissal in breach of the protection against occupational detriment is deemed to be automatically unfair dismissal for the purposes of the LRA. ${ }^{77}$ The PDA crossreferences to that Act and its applicable provisions. This was the route followed by Mr Charlton. The PDA then goes on to provide for protected disclosures made to the various categories of persons or bodies referred to in the definition of "protected disclosure" ${ }^{78}$ The PDA further provides for general protected disclosures. ${ }^{79}$

The PDA provides that the Minister responsible for the administration of justice may make regulations; this power must be exercised after consultation with the Minister responsible for the

73 Section 1

74 Section 3

75 Section 4.

76 Section 4(1)(a)

77 Section 4(2)(a).

78 Sections 5-8.

79 Section 9. 
public service and administration. ${ }^{80}$ Any regulations have to be submitted to Parliament before publication in the Government Gazette. ${ }^{81}$ The PDA further provides that the Minister must issue practical guidelines explaining the Act and the procedures available to employees desiring to make protected disclosures; this power must also be exercised after consultation with the Minister responsible for the public service and administration. ${ }^{82}$ Guidelines have been published, but only in 2011.83

\section{Labour Court}

As stated further above, Mr Charlton approached the Labour Court claiming that he had made protected disclosures regarding the misuse of travel benefits and that his dismissal was automatically unfair, or alternatively, unfair. Parliament raised several exceptions but the relevant one is that the claimant had not made protected disclosures; in amplification of this point of law, Parliament took exception on the basis that MPs were neither the employer of nor the employee of the claimant.

The Labour Court held that the business of Parliament is not the same as that of "ordinary enterprise"; Parliament's business is of its own kind and is defined in the Constitution. ${ }^{84}$ The Labour Court was satisfied that Parliament's business is to legislate for the Republic. ${ }^{85}$ The Court held that MPs fall within the definition of "employees" for the purposes of the PDA; they perform their duties as organs of state. ${ }^{86}$ The Court reiterated that MPs assist in the making of legislation and that the core business of the legislature is the enacting of legislation. ${ }^{87}$

The Court held that Parliament exists as a result of MPs and not the other way around. ${ }^{88}$ Parliamentary staff work for MPs and if there were no MPs then there would be no work for the staff to do; effectively, MPs provide staff with work and permit staff to assist them with various tasks. ${ }^{89}$ The Court also held that MPs did not have to formally employ or remunerate staff in order to be

80 Section 10(1).

81 Section 10(3).

82 Section 10(4)(a).

83 "Practical guidelines for employees in terms of section 10(4)(a) of the Protected Disclosures Act, 2000 (Act No 26 of 2000)" (31 August 2011) 702 Government Gazette 34572.

84 Charlton (LC), above n 2, at [19].

85 At [21].

86 At [22].

87 At [23].

88 At [25].

89 At [26]. 
"employers". ${ }^{90}$ It was not necessary to decide whether Parliament is a legal entity separate and distinct from its members because that question does not determine whether the PDA applies to MPs; further to this, neither the Constitution nor the Privileges Act expressly recognises Parliament as a separate entity. ${ }^{91}$ The Court relied on the State Liability Act 1957, which provides that parliamentary liabilities are to be paid out of the National Revenue Fund just like the salaries of MPs. ${ }^{92}$ The Court held that there was no reason to exclude MPs from the definition of "employer" under the PDA; it was also unnecessary to refer to the LRA because the PDA and LRA were enacted for different purposes. ${ }^{93}$ The Court viewed the arguments relating to parliamentary privilege as irrelevant. ${ }^{94}$ The Court noted Parliament's argument that MPs can act as whistleblowers but not under the protection of the PDA. ${ }^{95}$ This argument was rejected.

The Labour Court held that MPs make laws and one particular law, the PDA, defines "employee" and "employer"; the PDA is equivocal on whether MPs are "employees" or "employers". 96 The Labour Court then held that it does not make sense to argue that MPs enacted the PDA without intending it to apply to them; such an argument would make a "mockery" of the "whole legislation". 97

The Court also rejected the argument based on the South African Law Commission Discussion Paper, namely, that the paper had discussed the possibility of "extending" the ambit of the PDA. ${ }^{98}$ The Labour Court held that it was not bound by the paper. ${ }^{99}$ The Court then stated that the LRA, BCEA and PDA have the same definition of "employee" but only the PDA defines "employer". ${ }^{100}$

90 At [27].

91 At [31].

92 At [33].

93 At [34].

94 At [38].

95 At [41].

96 At [43].

97 At [45].

98 At [47]. See South African Law Reform Commission Discussion Paper 107: Protected Disclosures (SALRC, Project 123, 2004).

99 At [47].

100 At [50]. 
The Labour Court then recapped by stating that it had already found that MPs fall within the definition of "employer" and that they also have the characteristics of an "employee". ${ }^{101}$ The Labour Court dismissed the exceptions. ${ }^{102}$

\section{Labour Appeal Court}

Parliament appealed to the Labour Appeal Court. The Court framed the terms of its evaluation of the case as follows: 103

This case raises a novel issue as to whether parliamentarians are 'employees' or 'employers' as defined by the PDA. The outcome of this case will not only have an impact on the parties involved, but it will also affect the public. This court is mindful of the doctrine of separation of powers, which holds that the judiciary's function is to interpret the law and apply it even if the conclusion may lead to reprehensible conduct escaping scrutiny. Ultimately, this case hinges on statutory interpretation. In essence, this court must decide whether or not the application of 'employer' or 'employee' as defined in the PDA should be extended so as to include MPs.

It is clear from the above quote that the Court viewed the case as unprecedented. The Court understood the fundamental importance of separation of powers in the sense that its application may result in "reprehensible conduct escaping scrutiny". This is important. As an appellate court, the Labour Appeal Court had to be mindful of the broader constitutional effect of its judgment on the relationship between the legislature and the judiciary; it is arguable that the dominant organising principle of separation of powers can trump even the legitimate and pressing concerns of the aggrieved litigant. The Labour Appeal Court also stated that the outcome of the case hinged on statutory interpretation. The Labour Appeal Court then characterised the issue in terms that reflect a desire not to be seen to be rewriting the statute; this characterisation presents the case as being about whether a judge should extend the application of a statutory definition; in other words, and put in starker terms, the Labour Appeal Court asked whether the judiciary should step into the shoes of the legislature. It will be argued further below that this approach is consistent with the Labour Appeal Court's recognition of the fundamental importance of separation of powers under which Parliament makes law and courts interpret and apply it.

The Labour Appeal Court then referred to the presumption that the state is not bound by statute. The Labour Appeal Court noted that the court below had held that it would not make sense if MPs "made a law that does not or was not intended to apply to them" as this would "make a mockery to the whole legislation". ${ }^{104}$ It is submitted that the Labour Appeal Court's reference to the presumption

101 At [70].

102 At [74].

103 Charlton (LAC), above n 3, at [23].

104 At [24]. 
was a direct response to the Labour Court's reasoning that MPs could not have enacted a statute that did not apply to them. It might make sense under certain circumstances for an organ of state not to be bound by statute. In pointing this out, the Labour Appeal Court was exercising its supervisory jurisdiction over the Labour Court. Furthermore, the PDA does not contain the widely used provision: "This Act binds the State." The Constitution does not define "the state" but does define an "organ of State". ${ }^{105}$ The PDA's omission of this common provision may provide a further reason for the Labour Appeal Court's reference to the presumption.

The Labour Appeal Court held that the presumption would have to be developed in line with the new constitutional order premised on governmental accountability and transparency. ${ }^{106}$ The Court then held as follows: ${ }^{107}$

To hold that the provisions of the PDA bind MPs would hamper the execution of their duties and functions.

In any event Parliament has its own mechanism to deal with MPs whose conduct fails to pass muster.

This quote evidences that the Labour Appeal Court was of the view that the presumption had not been rebutted. It is crucial to remember that the case concerned a novel issue implicating separation of powers. Under the Constitution, Parliament has the right to control its own internal arrangements.

The Labour Appeal Court then turned to the question whether lawmakers are "employees" for the purposes of the PDA. The Court held as follows: ${ }^{108}$

To subject MPs to the PDA may, in practice, run the risk of frustrating the democratic process. An extension of the application of 'employee' under the PDA to include MPs might cause statutes to become more complex. MPs ought to be entirely independent.

Further to the above, the Court noted that: MPs hold an office; they are elected and have no recourse to Labour Court if they lose their seat; they take an oath of obedience to the Constitution; and they have a statutory right to remuneration; and they enjoy privileges that do not extend to ordinary citizens. ${ }^{109}$

The Court then agreed with Parliament's argument that the use of the same definition of "employee" in the LRA and the PDA strongly indicated the intention to create a single statutory scheme. The BCEA also has the same definition of "employee". The Court then relied on the House

105 My Vote Counts, above n 67, at [103].

106 Charlton (LAC), above n 3, at [25].

107 At [25].

108 At [27].

109 At [28] 
of Lords decision in Barras $v$ Aberdeen Steam Trawling as authority for its view. ${ }^{110}$ The Labour Appeal Court held as follows: ${ }^{111}$

[The Barras principle holds that] where a word of doubtful meaning has received a clear judicial interpretation, the subsequent statute, which incorporates the same word in a similar context, must be interpreted according to the meaning that was previously given to it. This occurs where the Legislature has repeated the word without alteration. This principle is applicable to the present case. Both the LRA and the PDA are firmly set within the employment law context. The PDA primarily concerns disclosures made within an employment relationship. MPs are excluded from the provisions of the LRA and therefore are also excluded from the PDA.

The Labour Appeal Court found that an even stronger indication of the creation of a single statutory scheme is the fact that $\mathrm{s} 187(1)(\mathrm{h})$ of the LRA, which deals with automatically unfair dismissal, specifically refers to the PDA; MPs are excluded from the LRA and therefore they are also excluded from the PDA. ${ }^{112}$ Incidentally, the LRA contains the provision: "This Act binds the State."113

The Court then addressed the question whether lawmakers are "employers" for the purposes of the PDA. The Court held that parliamentary staff are answerable to the Secretary of Parliament. ${ }^{114}$ The Labour Appeal Court held as follows: ${ }^{115}$

Parliamentarians must be allowed to focus on their constitutional duty to make law. A MPs portfolio ought not to be cluttered with the additional and onerous responsibilities of being an 'employer' of parliamentary staff. This would hinder the effective performance of their duties and functions.

The Labour Appeal Court upheld the appeal. ${ }^{116}$ But this was not the end of the matter. By way of legal artifice, the Supreme Court of Appeal ensured that the law is that contained in the Labour Court's judgment.

110 Barras v Aberdeen Steam Trawling [1933] AC 402 (HL).

111 Charlton (LAC), above n 3, at [29].

112 At [31].

113 Section 209.

114 Charlton (LAC), above $\mathrm{n} 3$, at [33].

115 At [33].

116 At [38]. 


\section{Supreme Court of Appeal}

Mr Charlton appealed to the Supreme Court of Appeal. ${ }^{117}$ The Supreme Court of Appeal upheld the appeal by relying on the general rule that the dismissal of an exception is not appealable. ${ }^{118}$ The Supreme Court of Appeal substituted the Labour Appeal Court's order with one striking out the appeal. ${ }^{119}$ Technically, the Labour Court's judgment is now law since the appeal against it was struck out. This article argues that something closer to the Labour Appeal Court's judgment ought to be the law.

\section{Post-Charlton parliamentary cases}

Over the past few years there have been several cases brought before the courts concerning "unparliamentary" conduct and the Office of the Speaker. ${ }^{120}$ These cases demonstrate the increasingly frequent interaction between the courts and Parliament. This is an unwelcome development.

The High Court interdicted the Speaker from implementing or enforcing the National Assembly's decision to suspend some opposition MPs' membership without remuneration or a fine in Economic Freedom Fighters $v$ Speaker of the National Assembly. ${ }^{121}$ During August 2014 the applicants had asked the President questions in Parliament regarding repayment of public money spent on his residence. ${ }^{122}$ The applicants found his answers to be insufficient. ${ }^{123}$ Much disorderly conduct ensued; security was called in; the business of the House was suspended; there was much banging on tables and chanting of "pay back the money". ${ }^{24}$ Allegations of gross disorder were referred to the Powers and Privileges Committee for investigation. ${ }^{125}$ There were counter-allegations that African National Congress members had also disrupted the business of Parliament but had not been dealt with in the

117 Charlton (SCA), above $\mathrm{n} 4$.

118 At [18].

119 At [25].

120 Lekota v Speaker, National Assembly [2012] ZAWCHC 385, 2015 (4) SA 133; Economic Freedom Fighters $v$ Speaker of the National Assembly [2014] ZAWCHC 204; Malema v Chairman of the National Council of Provinces [2015] ZAWCHC 39, 2015 (4) SA 145; Democratic Alliance v Speaker of the National Assembly [2015] ZAWCHC 60, 2015 (4) SA 351; Democratic Alliance v Speaker of the National Assembly [2016] ZACC 8, 2016 (3) SA 487; Tlouamma v Mbethe, Speaker of the National Assembly of the Parliament of the Republic of South Africa [2015] ZAWCHC 140, 2016 (1) SA 534.

121 Economic Freedom Fighters, above n 120, at 1.

122 At $8-9$.

123 At $8-12$.

124 At 12 .

125 At 13 . 
same way. ${ }^{126}$ The Court referred to the principle of parity of treatment despite the fact that it fell "within the context of labour law admittedly". ${ }^{127}$ The Court was nonetheless of the view that a similar principle would be applicable to the applicants. ${ }^{128}$ The Court also held that the applicants were not "aggrieved employees" but were public representatives paid to represent their constituents. ${ }^{129}$

This article submits that Economic Freedom Fighters highlights the dangers of viewing MPs in ordinary employment law terms. This is particularly so in the context of MPs attempting to hold the President to account for what they perceived to be corruption on his part. On the one hand, the Court said that something similar to the parity principle ought to apply to MPs. On the other hand, the Court expressly said that the MPs were not "aggrieved employees" but were rather public representatives. Similar difficulties would arguably arise if MPs were held to be employees or employers or both within the special meaning of those terms in the PDA.

The High Court upheld a constitutional challenge against the Privileges Act in Democratic Alliance $v$ Speaker of the National Assembly. ${ }^{130}$ There had been major disruptions during a joint sitting of Parliament convened for the President's State of Nation address. The Speaker invoked the Privileges Act by calling in parliamentary staff and "security forces" in order to forcibly remove the members belonging to the Economic Freedom Fighters. ${ }^{131}$ The applicant challenged the constitutionality of s 11 of the Privileges Act, which purported to authorise the Speaker and Chairperson to do so. ${ }^{132}$ Section 11 refers to "[a] person who creates or takes part in any disturbance in the precincts while Parliament or a House or committee is meeting"; the Court held that the impugned section applied to "members". The Court also held that the section is overbroad in that it permits MPs to be arrested for what they say on the floor of the House. ${ }^{133}$ Furthermore, Parliament had sufficient tools to maintain order; it had rules as well as the power to hold members in contempt. ${ }^{134}$ The Court declared the section inconsistent with the Constitution and invalid. ${ }^{135}$ However, the Constitutional Court declined to confirm the declaration of invalidity; rather, the

126 At 39.

127 At 39.

128 At 40.

129 At 45.

130 Democratic Alliance (ZAWCHC), above n 120.

131 At [1].

132 At [2].

133 At [43].

134 At [44].

135 At [48]. 
majority held that the invalidity of s 11 stemmed from the fact that it applied to MPs; ${ }^{136}$ the defect could be cured by reading in the phrase "other than a member" after "person" in s $11 .^{137}$ The majority then held that: "Insofar as members are concerned, it is within Parliament's remit to create a constitutionally compliant instrument to address disturbances where they are the culprits. "138 It is submitted that this reasoning strongly supports the LAC's reasoning in Charlton that the PDA does not apply to MPs in part because "Parliament has its own mechanism to deal with MPs whose conduct fails to pass muster". ${ }^{139}$

The latest case dealing with parliamentary matters and, more specifically, the nature of the Office of the Speaker is Tlouamma $v$ Mbethe, Speaker of the National Assembly of the Parliament of the Republic of South Africa. ${ }^{140}$ The case concerned a "three-pronged application" brought by three minority opposition parties. This article will only focus on the claim for the Speaker to be removed from office. The Speaker had allegedly failed to act in a neutral and fair manner; it was also alleged that the Speaker was no longer fit and proper to hold office. ${ }^{141}$ The matter concerned a motion of no confidence in the President, which was eventually scheduled for debate on 3 March 2015. On this day one of the applicants requested, first, that the Speaker recuse herself as presiding officer and, second, that the vote on the motion take place by secret ballot. These requests were refused. ${ }^{142}$ The Speaker opposed all the relief sought. ${ }^{143}$ This article focuses on those aspects of the judgment that concern the nature of the Office of the Speaker.

The Court extensively discussed the applicable constitutional and legislative framework with particular emphasis on the doctrine of separation of powers. ${ }^{144}$ The Court held that the Speaker's "powers, functions and duties are traditional and ceremonial, statutory, procedural and administrative". ${ }^{145}$ The Court also held that "[t]he Speaker has final authority in enforcing and interpreting the rules of the National Assembly." ${ }^{146}$ The Speaker also performs the "vital" function of

136 Democratic Alliance (ZACC), above n 120, at [59].

137 At [60].

138 At [60] (footnote omitted).

139 Charlton (LAC), above n 3, at [25].

140 Tlouamma $v$ Mbethe, above n 120.

141 At [1].

142 At [2].

143 At [6].

144 At [59]-[74].

145 At [75].

146 At [76]. 
maintaining order in the National Assembly. ${ }^{147}$ The Court then held that "[w]hile members of Parliament represent their individual constituencies, the Speaker represents the full authority of the House itself." ${ }^{148}$ And further that "[b]y common consent the Speaker's judgement is normally unquestioned and the Speaker is looked upon as the guardian of parliamentary democracy." ${ }^{149}$ The Court noted that there are no provisions in the Constitution that specifically provide for the role and powers of the Speaker. ${ }^{150}$ But the Speaker is the "administrative leader" of the National Assembly and as such is duty bound to uphold its dignity and authority. ${ }^{151}$ The application was dismissed.

The years since the Supreme Court of Appeal's judgment in Charlton have seen an alarming increase in the number of cases involving office-bearers in Parliament. These controversies pose serious constitutional questions about the status of MPs as well as the role of the Speaker. Despite the Supreme Court of Appeal's legal artifice in resolving the Charlton cases, this article submits that the Labour Court and Labour Appeal Court judgments are more relevant than ever before.

\section{Academic Criticism}

The Labour Appeal Court's judgment on the merits has come under some severe academic criticism. In particular, this article refers to Craig Bosch and Professor Rochelle Le Roux's article. ${ }^{152}$ The learned authors state that the decision is "haphazard" and the reasoning is "unconvincing". 153 Furthermore, the Court's characterisation of the issue is "not entirely correct"; the Labour Appeal Court had to determine whether Charlton's claims were disclosures for the purposes of the PDA; part of this issue relates to the question whether MPs are "employees" or "employers" for the purposes of the PDA; the Labour Appeal Court was therefore not required to decide whether the PDA ought to apply to MPs; this misplaced emphasis caused the Labour Appeal Court to make various errors in the course of its reasoning. ${ }^{154}$

The learned authors then dealt with the Labour Appeal Court's reference to the presumption that the state is not bound by statute. The authors stated that the Labour Appeal Court made no finding whether the presumption still has a place in a constitutional democracy; the Labour Appeal Court also

147 At [77].

148 At [78].

149 At [78].

150 At [82].

151 At [82].

152 Craig Bosch and Rochelle Le Roux "Not Letting Them Whistle: The Labour Appeal Court's Approach to the Protected Disclosures Act and Protecting Parliament's Employees" (2011) 32 Obiter 591.

153 At 594 .

154 At 594 . 
did not clarify the effect of the presumption on its reasoning; despite accepting that the presumption ought to be developed in line with the new constitutional dispensation, the Labour Appeal Court then went on to reason that MPs would be obstructed in the performance of their duties if employees could make disclosures relating to misconduct. ${ }^{155}$ The authors criticised the "startling conclusion" drawn by the Court; it also "beggars belief" to conclude that MPs could be hindered by the disclosure of unlawful conduct; it was also unclear as to precisely what additional obligations the PDA would place on MPs and the authors suggested that there would be none. ${ }^{156}$ Furthermore, the Labour Appeal Court did not provide any further explanation on the mechanisms that Parliament would use in order to deal with errant MPs. ${ }^{157}$ The Labour Appeal Court's judgment was further criticised on the basis that it did not consider whether the presumption had been rebutted. ${ }^{158}$ There were clear indications that the state ought to be bound by the PDA; these indications are to be found in the PDA and public policy. ${ }^{159}$

The authors then criticised the Labour Appeal Court's resolution of the question whether MPs are employees for the purposes of the PDA. The authors argued that the Labour Appeal Court's reasoning was "puzzling" and lacked any substantiation; it was difficult to understand how the application of the PDA to an MP's misconduct would frustrate the democratic process; rather, the contrary is true. ${ }^{160}$ The authors further argued that the Labour Appeal Court's view regarding the complexity of legislation was "incomprehensible"; the Court ought to have provided clear reasons for its "startling findings". 161

The authors conceded that MPs are not employees in the conventional sense and the usual hallmarks of the employment relationship are missing. ${ }^{162}$ However, the authors argued that MPs could be seen to be employees within the special meaning contained in the definition of "employee" for the purposes of the PDA and not the LRA. This is so because the context and purpose of the two enactments are different. ${ }^{163}$ The Labour Appeal Court's reasoning that there is a single statutory scheme between the LRA and the PDA is valid on its face but apparently disregards the different

155 At 595 .

156 At 595

157 At 595 .

158 At 596.

159 At 596

160 At 598 .

161 At 598 .

162 At 598 .

163 At 599 
legislative origins of the two Acts. ${ }^{164}$ The authors noted that the Acts are administered by different state departments. ${ }^{165}$

The authors also criticised the Labour Appeal Court's unitary conception of employment contracts, namely, that all types of employment are the same. ${ }^{166}$ This approach cannot accommodate the diverse types of employment that exist in a modern economy. ${ }^{167}$

The authors concluded that MPs are probably not employees. This is so because their office is incompatible with that of unelected positions in the civil service in terms of $\mathrm{s} 47$ of the Constitution as well as the fact that MPs have a statutory right to remuneration, amongst other reasons. ${ }^{168}$

The authors then moved to the question of whether MPs are employers for the purposes of the PDA. The authors answered this in the positive but not before offering further critical assessment of the Labour Appeal Court's decision. The authors argued that that the Labour Appeal Court's remarks about the cluttering of an MP's portfolio are "speculative" and not supported by any evidence. ${ }^{169}$

The authors conceded that para (b) of the definition of "employer" is "slightly ambiguous" but nonetheless concluded that a broader interpretation is required so as to include MPs within its ambit. ${ }^{170}$ The authors argued that the Labour Appeal Court fatally omitted the objects of transparency and accountability in interpreting the PDA. ${ }^{171}$ The authors also relied on fundamental rights such as the right to fair labour practices, freedom of expression, access to information and dignity. ${ }^{172}$ The authors also criticised the "serious omission" on the part of the Labour Appeal Court in that the Court omitted to mention the relevant international instruments. ${ }^{173}$

In sum, the authors concluded that the Labour Appeal Court had failed to demonstrate its specialist status in labour law. The Court had also failed to provide proper guidelines as supervisor of the development of labour relations policy and case law. ${ }^{174}$

164 At 599.

165 At 599

166 At 600

167 At 600 .

168 At 601

169 At 602

170 At 603 .

171 At 603.

172 At 604-609.

173 At 609 .

174 At 612. 
One solution has been suggested by Nicola Smit and MM Botha. ${ }^{175}$ They claim that the best option is to amend the PDA. ${ }^{176}$ The amendment would list MPs in the definition of "employee" so that they are deemed to be employees for the purposes of the PDA. ${ }^{177}$

\section{Rejoinder and Defence}

The academic criticism above totally overlooks the doctrine of separation of powers. The Charlton case raised a novel issue. Courts approach such cases from first principles. ${ }^{178}$ Charlton directly implicated the constitutional relationship between the judiciary and the legislature; a court had to determine whether national legislation applied to lawmakers; it is submitted that separation of powers comes to the fore in such cases.

It is further submitted that separation of powers influenced the Labour Appeal Court's characterisation of the issue. The Court was concerned not to judicially extend the statutory definition. It is argued that, while the primary question was whether Mr Charlton had made protected disclosures, the doctrine of separation of powers was foremost in the Labour Appeal Court's mind. It is further argued that the Labour Appeal Court was justified in focusing on the effect that its judgment would have on Parliament in general and MPs in particular. The more constitutionally relevant question was whether MPs were to be considered as employees or employers for the purposes of the PDA. This is particularly so given the specific references to these words in the Constitution.

The learned authors are also selective in their reliance on constitutional provisions. Proportionality is the hallmark feature of the Constitution. ${ }^{179}$ The authors make no attempt to view transparency and accountability in proportion to parliamentary rights. These rights would include the National Assembly's right to determine and control its internal arrangements, proceedings and procedures, ${ }^{180}$ and privilege rights. ${ }^{181}$ Ironically, MPs must enjoy parliamentary non-accountability in order to hold the executive accountable.

As discussed above, the learned authors argued that the Labour Appeal Court's reasoning that there is a single statutory scheme between the LRA and the PDA apparently disregards the different

175 Nicola Smit and MM Botha "Is the Protected Disclosures Act 26 of 2000 Applicable to Members of Parliament?" (2011) 4 TSAR 815.

176 At 828

177 At 829 .

178 Roux v Hattingh [2012] ZASCA 132, 2012 (6) SA 428 at [42].

179 Company Secretary of Arcelormittal South Africa v Vaal Environmental Justice Alliance [2014] ZASCA 184, 2015 (1) SA 515 at [73].

180 The Constitution of the Republic of South Africa, s 57.

181 Powers, Privileges and Immunities of Parliament and Provincial Legislatures Act 2004 (SA). See also The Constitution of the Republic of South Africa, s 58(2). 
legislative origins of the two Acts. But this argument can be rebutted by reliance on Arse v Minister of Home Affairs regarding the formation of one statutory system. ${ }^{182}$ The Supreme Court of Appeal held: 183

In so far as there may be a conflict between the two provisions they should be reconciled. Where two enactments are not repugnant to each other, they should be construed as forming one system and as reenforcing one another. In Petz Products v Commercial Electrical Contractors it was said: ${ }^{184}$

Where different Acts of Parliament deal with the same or kindred subject-matter, they should, in a case of uncertainty or ambiguity, be construed in a manner so as to be consonant and inter-dependant, and the content of the one statutory provision may shed light upon the uncertainties of the other.

Both the LRA and the PDA are set within the employment law context. The Acts are not repugnant to each other. Rather, they reinforce each other. Both Acts cross-reference the other. The LRA was enacted before the PDA. And the PDA replicates the definition of "employee" contained in the LRA. The PDA began as the generic Open Democracy Bill and was subsequently split into two separate Acts.

Further to the above, it is submitted that there is nothing constitutionally significant in the fact that the LRA and the PDA are administered by different state departments. This is because of the fluid nature of state departments, which often change after a new government is formed. Pursuant to the 2014 general elections, the President published a proclamation transferring the administration and powers and functions of specified legislation to various Cabinet members. ${ }^{185}$ The Cabinet members are executive authorities for the various departments. Notably, the administration of one piece of legislation was transferred from the Minister of Home Affairs to the Minister of Communications; another piece of legislation was transferred from the Minister for the Public Service and Administration to the Minister of Telecommunications and Postal Services. ${ }^{186}$ The President even created a new minister, the Minister of Small Business Development, and transferred legislation from the Minister of Trade and Industry to this new Minister. ${ }^{187}$ It is clear that the argument that the LRA and the PDA are administered by different state departments is a makeweight argument at best. The

182 Arse v Minister of Home Affairs [2010] ZASCA 9, 2012 (4) SA 544.

183 At [19].

184 Petz Products v Commercial Electrical Contractors 1990 (4) SA 196 (C) at 204.

185 "Transfer of administration and powers and functions entrusted by legislation to certain Cabinet members in terms of section 97 of the Constitution" (15 July 2014) 47 Government Gazette 37839.

186 At $4-5$.

187 At 8 . 
President may in the future decide to reconstitute the ministries and transfer the administration of legislation accordingly.

This article concludes that the Labour Appeal Court's merits judgment was the result of defects in the legislative framework rather than judicial error. The Labour Appeal Court was correct to hold that the PDA does not apply to MPs. It is not for the courts to debate the merits of legislation.

\section{NEW ZEALAND}

\section{A Fundamental Structure}

Geoffrey Palmer's recent book entitled Reform: A Memoir describes New Zealand's "Constitution" as being "unique" and "odd". ${ }^{188}$ Palmer also notes that New Zealand does not have a "Constitution" in the same sense as the United States or South Africa. ${ }^{189}$ Palmer states: ${ }^{190}$

The Parliament passes laws, levies taxes and controls government expenditure. Elections are required to be held every three years and they are held under a system of mixed-member proportional representation (MMP). The Cabinet, the members of whom must be members of Parliament, governs. Members of Cabinet must maintain the confidence of Parliament in order to remain in office. The public service operates under the authority of ministers and must carry out their decisions. The courts operate independently of both Parliament and the executive branch of government, which consists of Cabinet and the public service. Parliament creates the law and the courts decide disputes according to these statutes, but the role of interpreting the law in any particular case falls to the courts, not to Parliament. If the result is not to Parliament's liking, it can amend the law. The judiciary is shielded by law from interference by ministers. The judiciary is the main protector of the important constitutional norm of the rule of law. Clearly, public power is not distributed evenly among these three branches of government. Parliament has most power.

The Constitution Act 1986 provides that the House of Representatives is always in existence notwithstanding dissolution or expiration of Parliament. ${ }^{191}$ The members of the House consist of those persons elected from time to time in accordance with the Electoral Act 1993; these members are to be known as Members of Parliament. ${ }^{192}$ MPs are required to take an oath of allegiance. ${ }^{193}$ The Speaker

188 Palmer, above n 22, at 337.

189 At 338

190 At 339 (footnote omitted).

191 Section 10(3).

192 Section 10(4).

193 Section 11. 
is elected by the House and continues in office notwithstanding dissolution or expiration of the Parliament. ${ }^{194}$ Parliament consists of the Sovereign in right of New Zealand and the House. ${ }^{195}$

\section{B Legislative Framework}

The impetus for the New Zealand PDA was a matter involving a nurse, Mr Pugmire, who had warned hospital management against the release of a psychiatric patient into the community. The patient was nonetheless released and was subsequently found to have committed sexual offences against children. ${ }^{196}$ In Pugmire v Good Health Wanganui Ltd (No 2) the facts were that Mr Pugmire had released confidential patient material to an MP in an attempt to blow the whistle on wrongdoing within the hospital. ${ }^{197}$ The applicant had been compelled to accept either demotion or dismissal for breaching patient confidentiality. He applied for urgent interim relief declaring that this compulsion frustrated his legitimate expectation of natural justice as well as his expectation that his grievance procedure would be resolved first, amongst other relief. Although the application was granted, the case highlighted the lack of protection for employees making such disclosures in the public interest.

Some years later Parliament enacted the PDA. The purpose of the Act is to promote the public interest by facilitating the disclosure and investigation of serious wrongdoing and protecting employees who make such disclosures. ${ }^{198}$ A disclosure can be made to an "appropriate authority" but the PDA expressly excludes a Minister of the Crown and an MP from the definition of this phrase. ${ }^{199}$ This is the only part of the PDA that expressly refers to MPs. The PDA defines "employee" as follows: ${ }^{200}$

employee, in relation to an organisation, includes-

(a) a former employee:

(b) a homeworker within the meaning of section 5 of the Employment Relations Act 2000:

(c) a person seconded to the organisation:

(d) an individual who is engaged or contracted under a contract for services to do work for the organisation:

194 Sections $12-13$.

195 Section 14(1).

196 David McGee "Ombudsmen and officers of Parliament: Ombudsmen - whistleblowing" (20 January 2017) Te Ara, The Encyclopaedia of New Zealand <www.teara.govt.nz〉.

197 Pugmire v Good Health Wanganui Ltd (No 2) EmpC Wellington BC199471183, 10 March 1994.

198 Protected Disclosures Act 2000, s 5.

199 Section 3(1), definition of "appropriate authority", para (d).

200 Section 3(1). 
(e) a person concerned in the management of the organisation (including a person who is a member of the board or governing body of the organisation):

(f) in relation to the New Zealand Defence Force, a member of the Armed Forces:

(g) a person who works for the organisation as a volunteer without reward or expectation of reward for that work ...

The PDA also defines an "organisation" and "public sector organisation". An "organisation" means: ${ }^{201}$

... a body of persons, whether corporate or unincorporate, and whether in the public sector or in the private sector; and includes a body of persons comprising 1 employer and 1 or more employees ...

The definition of "organisation" refers to the public sector and the legislature chose to specifically define "public sector organisation"; the relevant part of "public sector organisation" means the Office of the Clerk of the House and the Parliamentary Service, amongst other organisations. ${ }^{202}$ The specific definition of "public sector organisation" trumps the more general definition of "organisation". Moreover, the latter definition refers to "employer" and "employees" indicating conventional employment relations governed by ordinary labour law. This article reiterates the difficulties identified by Geoffrey Palmer in trying to define an MP's role in society; as stated above, there is no adequate definition for an MP's portfolio. And Parliament wisely elected not to attempt to define an MP's office in discrete legislation such as the PDA.

Further to the above, the threshold set by the PDA is that of "serious wrongdoing"; one type of wrongdoing concerns "an unlawful, corrupt, or irregular use of funds or resources of a public sector organization". ${ }^{203}$ What if MPs were found to have used parliamentary travel funds in a corrupt manner?

The PDA sets out the type of disclosures to which the Act applies. The interpretation section contains the phrase "protected disclosure of information", which cross-references to s 6(2) of the PDA. ${ }^{204}$ Section $6(1)-(2)$ of the PDA read as follows:

\section{Disclosures to which Act applies}

(1) An employee of an organisation may disclose information in accordance with this Act if-

(a) the information is about serious wrongdoing in or by that organisation; and

201 Section 3(1).

202 Section 3(1), definition of "public sector organisation", paras (d)-(e).

203 Section 3(1), definition of "serious wrongdoing", para (a).

204 Section 3(1). 
(b) the employee believes on reasonable grounds that the information is true or likely to be true; and

(c) the employee wishes to disclose the information so that the serious wrongdoing can be investigated; and

(d) the employee wishes the disclosure to be protected.

(2) Any disclosure made in accordance with subsection (1) is a protected disclosure of information for the purposes of this Act.

The PDA is clear that the serious wrongdoing must have occurred in an organisation or have been committed by that organisation. And it is arguable that MPs do not fall within the definition of either "organisation" or "public sector organisation". Therefore, it is further submitted, the PDA does not bind MPs at all. They are neither an appropriate authority to whom disclosures can be made nor are they legally liable for serious wrongdoing.

The PDA must be understood in the context of other statutes relating to Parliament. The first is the Clerk of the House of Representatives Act 1988. There is a hierarchy in Parliament: the Clerk, the Deputy Clerk and the acting Clerk. ${ }^{205}$ The Clerk of the House is established as an office; ${ }^{206}$ the Clerk is the principal officer and is responsible to the Speaker for the efficient, effective and economic management of the office. ${ }^{207}$ The Act also deals with the State Services Commissioner in relation to the office; ${ }^{208}$ the Commissioner is the nominal employer of the Clerk but must exercise his or her functions consistently with the office's role and its separation from executive government. ${ }^{209}$

The next statute is the Parliamentary Services Act 2000. The General Manager is the administrative head of the service and is responsible to the Speaker. ${ }^{210}$ The service provides administrative and support services to the House and MPs; ${ }^{211}$ and, with the Speaker's approval, the service may also provide services to the following: any officer of the House, any officer of Parliament, any office of Parliament and any department or other instrument of the Crown. ${ }^{212}$ The State Services Commissioner performs the same role as the Clerk of the House. ${ }^{213}$

205 Clerk of the House of Representatives Act 1988, ss 2, 4 and 6.

206 Section 14

207 Sections 15-16.

208 Section 17.

209 Section 17(1A).

210 Parliamentary Service Act 2000, ss 10-11.

211 Section 7(a).

212 Section 9(1)(a)-(d).

213 Schedule 1 cl 15(1A). 
The next chronological statute is the Members of Parliament (Remuneration and Services) Act 2013. This Act provides for the remuneration of MPs by the Remuneration Authority. ${ }^{214}$ It is cited in support of the proposition that MPs are not "employees" for the purposes of the PDA. This is so because they hold an office and have a statutory right to remuneration, which is set by an authority rather than an employer in the conventional sense.

MPs enjoy privileged status under the Parliamentary Privileges Act. The main purpose of the Act is to "reaffirm and clarify the nature, scope, and extent of the privileges, immunities, and powers exercisable by the House of Representatives, its committees, and its members". 215 The other main purpose is to adequately protect MPs from exposure to civil and criminal liability for "communication of, and of documents relating to, proceedings in Parliament". ${ }^{216}$ A subsidiary purpose is to alter the law relating to "proceedings in Parliament" by way of legislative reversal of Attorney-General $v$ Leigh. ${ }^{217}$ The Act goes further and specifically implicates the doctrine of separation of powers; the Act must be interpreted in a manner that "promotes the principle of comity" between the courts and Parliament. ${ }^{218}$

\section{Probable Outcome in Court}

To date, the issue as to whether the PDA binds MPs has not come before the courts. The PDA has been referred to in several decisions but none of them involved protected disclosures made against MPs for any serious wrongdoing. ${ }^{219}$

Significantly, the PDA defines "employee" but not "employer". This article submits that MPs are not employees as defined. They hold an office and have a statutory right to remuneration. The job of a civil servant employed within the state service is incompatible with the office of an MP. Furthermore, MPs would not need the benefit of the PDA since they can rely on their privileges in disclosing any serious wrongdoing.

If the Charlton controversy were ever to occur in New Zealand, this article argues that the courts would have an easier task of interpreting and applying the legislative framework than the Labour Appeal Court in South Africa. Although the primary question in New Zealand would be whether a protected disclosure had been made, the PDA is clear that the serious wrongdoing must have occurred

\footnotetext{
214 Section 8 .
}

215 Section 3(1)(a).

216 Section 3(1)(b)

217 Attorney-General v Leigh [2011] NZSC 106, [2012] 2 NZLR 713.

218 Section $4(1)(b)$.

219 See Timmins v Legal Aid Review Panel [2004] 1 NZLR 708 (HC); Reeves v OneWorld Challenge LLC [2006] 2 NZLR 184 (CA); Solicitor-General v Miss Alice [2007] 2 NZLR 783 (HC); and Jeffries v Privacy Commissioner [2010] NZSC 99, [2011] 1 NZLR 45. 
in an organisation or have been committed by that organisation. MPs are not included in the definition of "organisation" or "public sector organisation". The PDA does not bind MPs at all. They are neither an appropriate authority to whom disclosures can be made nor are they legally liable for serious wrongdoing. The current structure of the PDA does not allow for a finding that MPs are bound by its contents. The courts are bound by law and would probably interpret the legislative framework so as to exclude MPs from its ambit.

\section{CONCLUSION}

This article concerned the theory of the relationship between the judiciary and the legislature. It considered the question whether lawmakers in South Africa and New Zealand are bound by a particular law they happened to make, namely, the PDA. Technically, in South Africa, MPs are bound since the LC's judgment in the Charlton case now stands as law. This article nonetheless sought to defend the Labour Appeal Court's merits judgment against strong academic criticism. It was argued that the judgment was the result of defects in the legislative framework rather than judicial error. The article also argued that if similar litigation were to occur in New Zealand, then it is probable that the courts would not bind MPs to the PDA. 